\title{
American and Macau student perceptions towards working in the tourism and hospitality industry
}

Carolin Lusby

Florida International University

\section{Recommended Citation}

Lusby, C. (2017). American and Macau student perceptions towards working in the tourism and hospitality industry. International Interdisciplinary Business-Economics Advancement Journal, 2(1), 54-64.

\section{Revisions}

Submission date: Oct. 25, 2016

1st Revision: Feb. 3, 2017

2nd Revision: Feb. 8, 2017

Acceptance: Feb. 25, 2017 


\title{
American and Macau Student Perceptions Towards Working in the Tourism and Hospitality Industry
}

\author{
Carolin Lusby \\ Chaplin School of Hospitality and Tourism Management \\ Florida International University, USA \\ clusby@fiu.edu
}

\begin{abstract}
This study examined the attitudes and perceptions of Chinese students studying in Macau and American students studying at a major public university in the USA. Through one-way analyses of variance, the two groups were compared regarding their perceptions and attitudes towards the tourism industry. The scale was adopted from previous studies and had been tested for reliability and validity. The survey was uploaded to an online survey site and the link emailed to students at the two universities. Results showed major significant differences between the two groups. American students in general proved to have more positive feelings towards a career in tourism, opportunities for promotions and pay. The findings of this study seem to suggest that students in Macau should be better counseled about career options in the industry. Furthermore, on a managerial and policy level more efforts should be made for more stability in the industry with adequate working hours, pay and benefits.
\end{abstract}

Keywords: hospitality students, perceptions and attitudes, career, nationality

\section{Introduction}

The purpose of this study was to compare Chinese and American college students in regards to their perceptions of hospitality and tourism education as well as attitudes towards the industry. Previous studies have examined the attitudes, perceptions and behaviors of tourism service employees, arguing the importance of positive employee attitudes towards achieving customer satisfaction (Choi, Kwon, \& Kim, 2013; Heskett, Jones, Loveman, Sasser, \& Schlessinger, 1994; Wan, Wong, \& Kong, 2014; Zeithaml, Bitner, \& Gremler, 2006). The tourism industry involves both direct and indirect interactions between employees and guests. These interactions create the quality of service consumers perceive, which in turn then leads to customer loyalty and satisfaction (Heskett et al. 1994; Sachdev \& Verma, 2002). Studies further pointed out that a competitive advantage through employees necessitates a well-trained, skilled, motivated and committed workforce (Kusluvan \& Kusluvan, 2000). These authors further expressed that there is a scarcity of studies examining the attitudes of students studying tourism and hospitality.

Based on the ideas of Fishbein and Aijzen (1975), attitudes influence behavior, which would make a positive attitude towards the industry an important trait of employees and would influence determination to work in the industry and lastly lower turnover rates. As such, understanding perceptions of students towards the industry might help better predict career 
success. Furthermore, theoretical models explaining the process of career choice of students also help in setting the theoretical model for this study. As such, Harren (1979) argues that students pass through four stages: awareness, planning, commitment and implementation. Robitschek and Cook (1999) built on Harren's framework by combining the awareness and planning stage. The authors further expanded the model investigating factors such as coping mechanisms, personal growth initiatives, vocational identity (intention to work in industry) and career exploration. Hence, based on these theoretical models, the perception of having a character and lifestyle that is suited for the tourism industry, opportunities to explore careers in the field and the ability to cope might all influence perceptions of the industry and ultimately career choices. Furthermore, it could be argued that differences in the perception of the industry or differences of selection of a specific major in college could potentially correlate to differences in perceptions of the industry between the two groups being studied.

This study further built on the work of Kusluvan and Kusluvan (2000) who developed and tested a reliable and valid scale to measure attitudes and perceptions of tourism and hospitality students in Turkey. The current study sought to examine and compare the attitudes and perceptions of Chinese students studying tourism and hospitality at a major university in Macau with American students studying tourism and hospitality at a major public university in the USA.

\section{Literature Review}

\section{Attitudes and Perceptions of Work Satisfaction}

Based on the studies cited above, it is vital for hospitality companies to understand employees' attitudes and perceptions of the industry to attract and retain employees that will stay and be successful in the workplace (Richardson, 2008, \& Richardson, 2009) and to build up a more enthusiastic workforce (Kusluvan \& Kusluvan, 2000; Richardson, 2010).

While it may not be clear whether job satisfaction directly affects work performance (Iaffaldano \& Muchinsky, 1985), research shows that it is correlated to important work-related outcomes such as organizational commitment (Mathieu \& Zajac, 1990), pro-social behavior (Bettencourt \& Brown, 1997), and corporate citizenship (Organ \& Lingl, 1995; Organ \& Ryan, 1995). Further, job satisfaction has been linked to customer satisfaction- both directly (Testa, Skaruupa, \& Pietrzak, 1998), and indirectly (Hallowell, Schlesinger, \& Zornitsky, 1996). Thus, employees who have positive attitudes toward the industries and their jobs are more likely to deliver better service, leading to greater customer satisfaction and loyalty (Wan, Wong, \& Kong, 2014; Zeithaml et al., 2006).

\section{Why Focus on Hospitality Students in This Paper}

The development of the global hospitality and tourism industry has brought in a large number of job opportunities (Richardson, 2008; International Labor Union [ILO], 2011). However, the industry has struggled in attracting and retaining workers (Lam \& Ching, 2007), resulting in a shortage of skilled employees in the growing hospitality business (Baum, 2006; Richardson, 2010). Richardson (2008) shockingly discovered that over half of Australian hospitality and tourism students chose a career other than the hospitality industry. Similarly, research from Hong Kong suggests that a majority of hospitality students did not want to join the industry after 
graduation (Chang \& Tse, 2011). Furthermore, a study from Ireland highlighted a high dropout rate from the hospitality and tourism industry (O'Leary \& Deegan, 2005).

While other factors add to the problem, researchers agree that negative attitudes seem to be the main issue (Kusluvan \& Kusluvan, 2000; Teng, 2008). These include assumptions of low financial compensation, unsociable working hours, and limited opportunities for career progression. These characteristics may result in low job satisfaction and a high turnover rate (Roney \& Oztin, 2007). Research has suggested that students are able to improve their job satisfaction and decrease dropout rates by forming more realistic expectations of the hospitality industry and their careers (Aycan \& Fikret-Pasa, 2003; Wan \& Kong, 2012).

Hospitality and tourism scholars have been interested in determining the factors that influence students career decisions. As such, Kim, McCleary, and Kaufman (2010) concluded that U.S. hospitality students consider primary information sources (e.g., work experiences, personal experiences) as more influential than secondhand sources (e.g., class materials, faculty) in career decisions. These researchers further found that for American hospitality students, extrinsic factors (e.g., advancement chances, job security) were far more influential than intrinsic factors (e.g., public status, service to society) among the eight identified factors (people relations, service to society, job security, public status, advancement chances, job autonomy, leadership development, working environment). Hence, an increased understanding of student perceptions could help managers to attract talent, create more work place performance and lower turnover rates (Zeithaml et al., 2006). Previous research also seems to show strong cross-cultural differences in perceptions of the industry (Kim et al, 2010; Kusluvan \& Kusluvan, 2000). A review of the literature showed a gap in the literature in regards to research comparing different cultural groups of students. As such, this study aims at comparing the attitudes of American and Chinese students.

\section{Chinese Hospitality Student Market}

China is becoming increasingly significant in the global market, as more and more international companies worldwide are attracted to the country and wish to make investments within its vast borders (Wong \& Liu, 2009). For the international organizations investing and operating in the hospitality and tourism industry in China, Chinese hospitality and tourism management students form a major source of labor. In order to deliver high standards of service, these organizations have been working hard to attract a large group of qualified workers by developing effective and efficient recruitment and workplace strategies (Wong \& Liu, 2009). However, according to Xu (2005), only 10-20\% of hospitality graduates serving in the industry were educated at comprehensive universities or institutions. Evidence also suggests that over $20 \%$ of hospitality employees choose to leave their first employer for other industries after short periods of time (Wong \& Liu, 2009). Hence, a clear understanding of the attitudes and preferences of hospitality students toward the industry and their jobs can help international hospitality and tourism organizations to better attract and retain well-qualified employees.

Finally, globalization has drastically changed the service industry by opening the door to multinational companies doing business in a variety of countries (Chang \& Tse, 2011), Hence, creating a need to understand attitudes and perceptions of different nationalities is becoming evident. Through the review of the literature, a clear gap in studies on cross-cultural 
comparisons of student perceptions of the industry became apparent. The purpose of this study then is to examine the similarities and differences between Chinese hospitality students studying in Macau and American hospitality students studying in Miami. The instrument was adapted from the multi-dimensional and multi-item attitude scale developed by Kyriacou and Coulthard (2000) who studied undergraduate education students in New York. The current study instrument further built on the work of Kusluvan and Kusluvan (2000) who studied undergraduate tourism students' attitudes towards working in the tourism industry and found that most study participants held negative perceptions of the industry. The authors believe that the findings of the current study will contribute to the literature by providing a comparative study of factors influencing attitudes and perspectives of two different groups of hospitality students toward the tourism and hospitality industry. Results will also help multinational organizations to better understand workforce demands to recruit and retain the most professional employees in the hospitality and tourism industry.

\section{Methodology}

A total of 535 university students studying in Macau and Miami participated in this study. The final sample consists of 422 American students and 113 Chinese students. The survey included demographic questions such as gender and educational level. A five point Likert scale $(5=$ completely agree, $4=$ agree, $3=$ neutral, $2=$ disagree, $1=$ completely disagree) measured attitudes of students towards nine dimensions: (1) nature of work, (2) social status, (3) industry/person congeniality, (4) physical working conditions, (5) pay/fringe benefits, (6) promotion, (7) coworkers, (8) managers, (9) commitment to the industry. The instrument had been tested for reliability and validity (Kuslavan \& Kuslvana, 2000). Furthermore use of an existing scale enables the researchers to compare present findings to previous studies. The online survey was sent to hospitality students currently enrolled at the two universities in Macau and the USA. A quantitative approach was chosen to adequately compare the two groups. Data were analyzed using a statistical software packages (SPSS). One Way ANOVAS compared the two groups on the items with a chosen $\mathrm{p}$ value of.05.

\section{Results and Discussions}

Both the American and Chinese respondents were mostly female (74.5 percent \& 84.1 percent). As for the educational level, most American students were in their senior (65.6 percent) or junior year (30.6 percent), while most Chinese students were seniors (49.6 percent) or freshmen (24.8 percent).

\section{Characteristics of Survey Sample}

Among these students, 86.5 percent of American students and 69.9 percent of Chinese students chose the major independently and willingly. It is interesting to note here that the percentage of Chinese students who did not choose their major freely is much higher. Nevertheless, when respondents were asked to choose the top four areas or industries they want to work in after graduation, tourism (83\% and 63.7\%) and the hotel industry (74.5\% and $85.9 \%$ ) ranked high for American and Macau students, suggesting both groups chose the major to prepare for a career in the industry. 


\section{Comparison of Perceptions and Attitudes of Hospitality Students Towards Working in the Tourism Industry Between America and Macau}

A one-way ANOVA analysis determined whether there were differences between students' nationality and perceptions/attitudes toward careers in the tourism and hospitality industry. Independent t-tests were performed to examine these differences within each category. Results indicate that overall American students tend to feel more positive about the industry in general as can be seen in table one below.

Table 1: Career Choice

\begin{tabular}{|c|c|c|c|c|c|c|}
\hline \multirow[t]{2}{*}{ Choosing Your Career } & \multicolumn{2}{|c|}{ American } & \multicolumn{2}{|c|}{ Macau } & \multicolumn{2}{|c|}{ Result } \\
\hline & Mean & SD & Mean & SD & $\mathbf{t}$ & p value \\
\hline A job that I will find enjoyable & 4.65 & 0.67 & 4.23 & 0.85 & 5.29 & 0.000 \\
\hline Colleagues that I can get along with & 4.37 & 0.78 & 3.99 & 0.88 & 3.95 & 0.000 \\
\hline A secure job & 4.41 & 0.85 & 3.61 & 0.93 & 8.22 & 0.000 \\
\hline A job where you gain transferable skills & 4.53 & 0.72 & 4.03 & 0.67 & 6.25 & 0.000 \\
\hline A job with high quality resources and equipment & 4.38 & 0.80 & 3.81 & 0.83 & 6.26 & 0.000 \\
\hline The opportunity to travel abroad & 4.43 & 0.88 & 3.98 & 0.86 & 4.56 & 0.000 \\
\hline Job mobility -- easy to get a job anywhere & 4.43 & 0.82 & 3.75 & 0.96 & 7.13 & 0.000 \\
\hline
\end{tabular}

The results showed that there were significant differences between the nationalities when it comes to the nature of work, social status, industry-person congeniality, physical working conditions, pay/benefits, promotion opportunities, coworkers, and commitment. There were no significant differences between a student's nationality and scores on physical working conditions and most items related to mangers. Macau students seem to have less faith in their managers, indicating that a perceived lack of value and respect for employees (p.05). This could explain why the industry as a whole is perceived as less positive to work for. Below is a more detailed summary of the main statistically different items.

\section{Nature of Work}

The one-way ANOVA was significant $F(2,293)=3.20, p=0.04$. American students had significantly higher scores $($ mean $=3.80, \mathrm{SD}=0.56$ ) than Macau students (mean $=3.52, \mathrm{SD}=$ 0.51). American students showed higher confidence in the tourism industry in comparison to Macau students. They see a professional future in the tourism industry, and the idea of working in a global field draws them to tourism. In particular, the significant (.05) t-test revealed that American students seem to find the tourism industry more interesting (mean $=4.49, \mathrm{SD}=0.667$ ) and have more fun to communicate with foreigners (mean $=4.43, \mathrm{SD}=0.716$ ) than Macau students do $($ mean $=3.76, \mathrm{SD}=0.695$; mean $=4.16, \mathrm{SD}=0.738)$. On the other hand, Macau students (mean $=2.7, \mathrm{SD}=0.89$ ) agree more with the statement that family life is negatively affected due to the nature of work than American students (mean $=2.98, \mathrm{SD}=1.035$ ) do. Both groups indicate that jobs in the tourism industry are low skilled and nonstable. Results are shown in table two below. 
Table 2: Nature of Work

\begin{tabular}{lllllll}
\hline Nature of Work & \multicolumn{2}{c}{ American } & \multicolumn{2}{c}{ Macau } & \multicolumn{2}{c}{ Result } \\
\hline & 4.49 & 0.66 & 3.76 & 0.69 & 9.62 & 0.000 \\
$\begin{array}{l}\text { I find jobs in the tourism industry } \\
\text { interesting }\end{array}$ & 2.31 & 0.95 & 2.27 & 0.88 & 0.23 & 0.818 \\
$\begin{array}{l}\text { Most jobs in the tourism industry are low } \\
\text { skilled }\end{array}$ & 4.43 & 0.71 & 4.16 & 0.73 & 3.24 & 0.001 \\
$\begin{array}{l}\text { It is nice to have the opportunity to } \\
\begin{array}{l}\text { communicate with foreigners while } \\
\text { working in the tourism industry }\end{array}\end{array}$ & & & & & & \\
$\begin{array}{l}\text { Family life is negatively affected for } \\
\text { people working in the tourism industry }\end{array}$ & 2.98 & 1.03 & 2.72 & 0.89 & 2.37 & 0.018 \\
$\begin{array}{l}\text { It is very difficult to find a stable job in } \\
\text { tourism }\end{array}$ & 2.66 & 0.94 & 2.81 & 0.89 & -1.43 & 0.152 \\
\hline
\end{tabular}

\section{Social Status}

The results of the one-way ANOVA $(\mathrm{F} 7.40, \mathrm{p}=0.00)$ are displayed in table three below and show that all items related to social status showed significant differences between the two groups with American students generally feeling more positive (mean $=3.67, \mathrm{SD}=0.61$ ) than Macau students (mean $=3.17, \mathrm{SD}=0.53$ ). T-tests revealed that, American students in general feel proud of their profession in tourism (mean $=4, \mathrm{SD}=0.827$ ) and perceive a tourism career as a respected (prestigious) vocation in society (mean $=3.69, \mathrm{SD}=0.886$ ), that garners family (mean $=4.12, \mathrm{SD}=0.743$ ) and societal respect (mean $=3.94, \mathrm{SD}=0.864)$. Macau students were not as positive $($ mean $=3.27, \mathrm{SD}=0.792$; mean $=3.21, \mathrm{SD}=0.828$; mean $=3.47, \mathrm{SD}=0.802$; mean $=3.77, \mathrm{SD}=0.739$ ). Both Macau and American students disagreed with the statement that tourism is not valued in society.

Table 3: Social Status

\begin{tabular}{lllllll}
\hline Social status & $\begin{array}{l}\text { Mean } \\
\text { American }\end{array}$ & SD & $\begin{array}{l}\text { Mean } \\
\text { Macau }\end{array}$ & SD & T & $\begin{array}{l}\text { P } \\
\text { Value }\end{array}$ \\
\hline $\begin{array}{l}\text { My family is proud of my profession in } \\
\text { tourism }\end{array}$ & 4.00 & 0.82 & 3.27 & 0.79 & 7.81 & 0.000 \\
$\begin{array}{l}\text { Working in tourism is a respected } \\
\text { (prestigious) vocation in society }\end{array}$ & 3.69 & 0.88 & 3.21 & 0.82 & 4.81 & 0.000 \\
$\begin{array}{l}\text { Working in tourism is regarded as an } \\
\text { important and beneficial service to }\end{array}$ & 3.94 & 0.86 & 3.77 & 0.73 & 1.81 & 0.070 \\
$\begin{array}{l}\text { society } \\
\begin{array}{l}\text { I think that those working in the tourism } \\
\text { industry are not valued in society }\end{array}\end{array}$ & 2.75 & 1.07 & 2.14 & 0.82 & 5.10 & 0.000 \\
$\begin{array}{l}\text { I talk to my relatives and friends with } \\
\text { pride about my vocation in the tourism } \\
\text { industry }\end{array}$ & 4.12 & 0.74 & 3.47 & 0.80 & 7.50 & 0.000 \\
\hline
\end{tabular}

\section{Industry-Person Congeniality}

Table four below displays $\mathrm{T}$ tests for the items under the industry-person congeniality factor. All items showed significant differences. American students feel that their character and skills fit the tourism industry and they get pleasure and satisfaction while working in this field. 
Table 4: T Tests

\begin{tabular}{lllllll}
\hline Industry-person Congeniality & $\begin{array}{l}\text { Mean } \\
\text { American }\end{array}$ & SD & $\begin{array}{l}\text { Mean } \\
\text { Macau }\end{array}$ & SD & T & P value \\
\hline $\begin{array}{l}\text { My character fits great for working in the } \\
\text { tourism industry }\end{array}$ & 4.37 & 0.68 & 3.57 & 0.93 & 9.47 & 0.000 \\
$\begin{array}{l}\text { I can use my abilities and skills in tourism } \\
\text { jobs }\end{array}$ & 4.46 & 0.61 & 4.00 & 0.62 & 6.49 & 0.000 \\
$\begin{array}{l}\text { I get pleasure while working in the tourism } \\
\text { industry }\end{array}$ & 4.33 & 0.73 & 3.65 & 0.71 & 8.09 & 0.000 \\
$\begin{array}{l}\text { I like to see satisfied customers when I } \\
\text { serve them }\end{array}$ & 4.58 & 0.59 & 4.35 & 0.65 & 3.29 & 0.001 \\
\hline
\end{tabular}

\section{Pay/Benefits}

The one-way ANOVA $(\mathrm{F}=3.39, \mathrm{p}=0.04)$ revealed that American students $($ mean $=2.85, \mathrm{SD}=$ 0.81 ) had significantly higher scores than Macau students (mean $=2.60, \mathrm{SD}=0.66$ ). As all the items in the domain of pay/benefits were negatively stated ("I think the pay is low for most jobs in the tourism industry"; "I think that the pay for most tourism jobs is not sufficient to lead a satisfactory life"), they were reverse-coded to be evaluated. The results show that American students perceive pay/benefits in the tourism industry more positively than Macau students.

Promotion opportunities

The one-way ANOVA, F $(10.44, \mathrm{p}=0.00)$ proved the two groups to be significantly different. American students (mean $=3.27, \mathrm{SD}=0.68$ ) had significantly higher scores than Macau students (mean $=2.90, \mathrm{SD}=0.53$ ). Some of the items under the promotion domain were reverse coded, as they were negatively stated including "The opportunity of getting promoted to managerial positions is limited in the tourism industry". Thus, since the result of the t-test was significant for these questions, American students agree that promotion opportunities are satisfactory in the tourism industry, while Macau students believe that the promotion opportunities are limited in the tourism industry. Macau students showed doubt about systematic and fair promotional systems.

Table 5: Differences Perception of Promotion Opportunities

\begin{tabular}{|c|c|c|c|c|c|c|}
\hline Promotion Opportunities & $\begin{array}{l}\text { Mean } \\
\text { American }\end{array}$ & SD & $\begin{array}{l}\text { Mean } \\
\text { Macau }\end{array}$ & SD & $\mathbf{T}$ & $\begin{array}{l}\mathbf{P} \\
\text { Value }\end{array}$ \\
\hline $\begin{array}{l}\text { Promotion opportunities are satisfactory in } \\
\text { the tourism industry }\end{array}$ & 3.59 & 0.77 & 3.25 & 0.71 & 3.93 & 0.000 \\
\hline $\begin{array}{l}\text { The opportunity of getting promoted to } \\
\text { managerial positions is limited in the } \\
\text { tourism industry }\end{array}$ & 2.96 & 0.90 & 3.38 & 0.84 & -4.05 & 0.000 \\
\hline $\begin{array}{l}\text { It is very difficult to get promoted if you } \\
\text { do not have 'an uncle in the court' (aka } \\
\text { connections) in the tourism industry }\end{array}$ & 2.83 & 1.00 & 3.11 & 0.85 & -2.51 & 0.012 \\
\hline $\begin{array}{l}\text { Promotions are unsystematic in the } \\
\text { tourism industry }\end{array}$ & 2.89 & 0.83 & 3.12 & 0.85 & -2.39 & 0.017 \\
\hline
\end{tabular}

\section{Coworkers}

$\mathrm{T}$ test for the items in this factor showed that American students (mean $=2.36$, versus mean=2.62) more strongly believe employees are generally educated in the tourism industry. American students (mean $=3.76, \mathrm{SD}=0.848$ ) agree that most employees are highly motivated and enthusiastic about working in the tourism industry, while Macau students (mean $=3.14, \mathrm{SD}=$ 
0.685) are less sure. However, both agree that generally people with an educational background in tourism work in the tourism industry.

\section{Commitment}

The one-way ANOVA, F (7.92, $\mathrm{p}=0.00)$ showed that American students had significantly higher scores $($ mean $=3.75, \mathrm{SD}=0.64$; mean $=3.45, \mathrm{SD}=0.55)$ than Macau students. The $\mathrm{t}$ tests displayed in table six below, show that students in Macau tend to believe that the disadvantage of working in the tourism industry outweigh the advantages, considering their choice in tourism as a mistake. American students see more advantages to working in the tourism industry, feel happy and like to put the effort in choosing a career in this field. They would recommend a tourism career to their friends and relatives and see promotional opportunities in this industry. Although both groups disagree that it is definite that they will not work in the tourism industry after graduation, American students show more commitment and higher enthusiasm to the tourism industry in comparison to Macau students.

Table 6: Differences Commitment to the Tourism Industry

\begin{tabular}{lllllll}
\hline Commitment to the Tourism Industry & $\begin{array}{l}\text { Mean } \\
\text { American }\end{array}$ & SD & $\begin{array}{l}\text { Mean } \\
\text { Macau }\end{array}$ & SD & T & P \\
\hline $\begin{array}{l}\text { In my opinion, the disadvantages of } \\
\text { working in the tourism industry outweigh } \\
\text { the advantages }\end{array}$ & 2.39 & 0.96 & 2.77 & 0.93 & -3.55 & 0.001 \\
$\begin{array}{l}\text { I am very happy to have chosen tourism as } \\
\text { a career path }\end{array}$ & 4.09 & 0.83 & 3.57 & 0.76 & 5.91 & 0.000 \\
$\begin{array}{l}\text { I would like to work in the tourism } \\
\text { industry after graduation }\end{array}$ & 4.05 & 0.92 & 3.68 & 0.75 & 3.54 & 0.000 \\
$\begin{array}{l}\text { I will not put great effort into acquiring a } \\
\text { job in the tourism industry }\end{array}$ & 2.25 & 1.19 & 2.66 & 0.89 & -3.11 & 0.002 \\
$\begin{array}{l}\text { It is definite that I will not work in the } \\
\text { tourism industry after graduation }\end{array}$ & 2.24 & 1.18 & 2.42 & 0.82 & -1.39 & 0.164 \\
$\begin{array}{l}\text { It was a big mistake to choose tourism as a } \\
\text { career path }\end{array}$ & 1.77 & 0.98 & 2.12 & 0.93 & -2.90 & 0.004 \\
$\begin{array}{l}\text { I recommend a job in the tourism industry } \\
\text { to my friends and relatives }\end{array}$ & 3.79 & 0.85 & 3.34 & 0.78 & 4.57 & 0.000 \\
$\begin{array}{l}\text { I would work only in high paid jobs in the } \\
\text { tourism industry }\end{array}$ & 3.38 & 0.89 & 3.13 & 0.85 & 2.42 & 0.016 \\
$\begin{array}{l}\text { I see my vocational (professional) future in } \\
\text { the tourism industry }\end{array}$ & 3.89 & 0.86 & 3.37 & 0.79 & 5.71 & 0.000 \\
$\begin{array}{l}\text { The idea of working in a global field with } \\
\text { international job and promotion } \\
\text { opportunities really draws me to tourism }\end{array}$ & 4.17 & 0.81 & 3.72 & 0.72 & 4.89 & 0.000 \\
\hline
\end{tabular}

In conclusion, significant differences can be found between the two groups. The study showed that attitudes towards working in the industry can be positive when students feel they have good pay and benefits, as well as chances of promotions.

\section{Conclusions}

The current study examined the attitudes of both American and Macau tourism students regarding working in the tourism and hospitality industry with a previously tested and reliable scale. One important finding of this study was that physical working conditions and managers make little difference in the willingness to work in the tourism and hospitality industry. Another 
important conclusion is that respondents from both areas share some negative attitudes towards the industry, such as unstable jobs, low skill set, low social status and low pay. In addition, both groups claimed that they might not work in tourism, which revealed that undergraduate students share a lack of commitment to industry. Last but not least, American students showed more faith and confidence in choosing a career in the industry. They feel the job is enjoyable, secure, resourceful and flexible with good colleagues, available transferable skills and opportunity to travel abroad, while Macau students showed less optimism in regards to these factors. It is interesting to note the significantly more negative attitudes of Macau students towards the industry. Future studies should investigate why there is such a difference in the two samples. Less freedom to speak and to be creative could be a leading cause. It is worth it to note here that Macau students agreed more with the statements that their character did not seem to fit the industry and that working in tourism is fun. Furthermore, the tourism industry is associated with labor of lower classes and as such not a desirable career (Zheng, 2008). Another noteworthy difference is that the educational system in China in essence assigns majors based on test scores, which forces students to accept a field of study, which might not be aligned with their career choice so they can attend the university they like. This of course could also explain the lower level of enthusiasm and intention to work in the industry. Accordingly, China has turnover rates in tourism of up to $35 \%$ after graduation (Zhao, 2008). Reexamining the model provided by Robitschek and Cook (1999); it could be argued that differences between the two groups could be largely due to a less favorable vocational identity of the tourism industry in China. This includes less chances of adequate career exploration in relation to a chosen fields of study (due to the educational system forcing students to study majors outside their field of interest), and perception of less coping mechanism to deal with the stresses of the industry. One solution then seems to be increased career counseling and required practicums for students in hospitality related majors in China in order to form realistic perceptions of the industry.

The negative attitudes that students potentially form during practical experiences may lead to negative consequences for the students, the tourism industry, the government, and tourism and hotel management schools (Kusluvan \& Kusluvan, 2000). Although American and Macau students showed varying degrees of such negative attitudes, the negative consequences would be equal. In order to attract and keep employees, it is important to change students' attitudes towards this industry from negative to positive. Firstly, tourism and hotel management schools could help students foster a realistic perspective about careers and working conditions in the industry and teach more problem-solving to better confront this highly stressful and ever changing industry. In this way, students are less likely to overestimate the tourism and hospitality industry and more likely to work through all the problems they encounter during work. Secondly, new policies for tourism and hospitality organizations recruiting higher education students could lead to new innovative ways industry and academics interface, leading to beneficial programs for both the companies and local economy. Then, these organizations can offer more scholarship opportunities, information sessions and campus recruitment to help students familiarize themselves with the industry and also give them more confidence in their education and career. Finally, a collaborative effort is needed to improve the working conditions enhancing the attractiveness of the industry to future students.

\section{References}

Aycan, Z., \& Fikret-Pasa, S. (2003). Career choices, job selection criteria, and leadership preferences in a transitional nation: The case of Turkey. Journal of Career Development, 30(2), 129-144. 
Baum, T. (2006). Human resource management for tourism, hospitality and leisure: An international perspective. London, UK: Thomson Learning.

Bettencourt, L. A., \& Brown, S. W. (1997). Contact employees: Relationships among workplace fairness, job satisfaction and prosocial service behaviors. Journal of Retailing, 73(1), 39-61.

Chang, S., \& Tse, C. (2011, July). Accounting for Hong Kong hospitality students' intention to join the industry: The role of service orientation, emotional intelligence, and satisfaction with the hospitality industry. Paper presented at the International CHRIE Conference, Denver, CO.

Choi, Y., Kwon, J., \& Kim, W. (2013). Effects of attitudes vs experience of workplace fun on employee behaviors: Focused on generation $\mathrm{Y}$ in the hospitality industry. International Journal of Contemporary Hospitality Management, 25(3), 410-427.

Fishbein, M., \& Ajzen, I. (1975). Belief, attitude, intention, and behavior: An introduction to theory and research. Boston, MA: Addison-Wesley.

Harren, V. A. (1979). A model of career decision making for college students. Journal of Vocational Behavior, 14(2), 119-133. http://dx.doi.org/10.1016/0001-8791(79)90065-4

Hallowell, R., Schlesinger, L. A., \& Zornitsky, J. (1996). Internal service quality, customer and job satisfaction: Linkages and implications for management. Human Resource Planning, 19(2), 20-31.

Heskett, J., Jones, T., Loveman, G., Sasser Jr., W., \& Schlesinger, L. (1994). Putting the service-profit chain to work. Harvard Business Review, 72, 164-174.

Iaffaldano, M. T., \& Muchinsky, P. M. (1985). Job satisfaction and job performance: A Meta-analysis. Psychological Bulletin, 97(2), 251-273.

International Labor Union. (2011). Employment in the tourism industry to grow significantly. Retrieved from http://www.ilo.org/global/publications/world-of-work-magazine/articles/WCMS_157893/lang-en/index.htm

Kim, B., McCleary, K. W., \& Kaufman, T. (2010). The new generation in the industry: Hospitality/tourism students' career preferences, sources of influences and career choice factors. Journal of Hospitality \& Tourism Education, 22(3), 5-11.

Kusluvan, S., \& Kusluvan, Z. (2000). Perceptions and attitudes of undergraduate tourism students towards working in the tourism industry in Turkey. Tourism Management, 21(3), 251-269.

Kyriacou, C., \& Coulthard, M. (2000). Undergraduates' views of teaching as a career choice. Journal of Education for Teaching, 26(2), 117-126.

Lam, T., \& Ching, L. (2007). An exploratory study of an internship program: The case of Hong Kong students. International Journal of Hospitality Management, 26(2), 336-351.

Mathieu, J., \& Zajac, D. (1990). A review and meta-analysis of the antecedents, correlates, and consequences of organizational commitment. Psychological Bulletin, 108(2), 171-194.

O'Leary, S., \& Deegan, J. (2005). Career progression of Irish tourism and hospitality management graduates. International Journal of Contemporary Hospitality Management, 17(5), 421-432.

Organ, D. W., \& Lingl, A. (1995). Personality, satisfaction and organizational citizenship behavior. Journal of Social Psychology, 135, 339-351.

Organ, D. W., \& Ryan, K. (1995). A meta-analytic review of attitudinal and dispositional predictors of organizational citizenship behavior. Personnel Psychology, 48(4), 775-802.

Richardson, S. (2008). Undergraduate tourism and hospitality students attitudes toward a career in the industry: A preliminary investigation. Journal of Teaching in Travel \& Tourism, 8(1), 23-46.

Richardson, S. (2009). Undergraduates' perceptions of tourism and hospitality as a career choice. International Journal of Hospitality Management, 28(3), 382-388.

Richardson, S. (2010). Generation Y's perceptions and attitudes towards a career in tourism and hospitality. Journal of Human Resources in Hospitality \& Tourism, 9(2), 179-199.

Robitschek, C., \& Cook, S. W. (1999). The influence of personal growth initiative and coping styles on career exploration and vocational identity. Journal of Vocational Behavior, 54(1), 127-141. http://dx.doi.org/10.1006/jvbe.1998.1650

Roney, S. A., \& Oztin, P. (2007). Career perceptions of undergraduate tourism students: a case study in Turkey. Journal of Hospitality, Leisure, Sport \& Tourism Education, 6(1), 4-18.

Sachdev, S., \& Verma, H. (2002). Customer expectations and service quality dimensions consistency. Journal of Management Research, 2(1), 43-52.

Teng, C. C. (2008). The effects of personality traits and attitudes on student uptake in hospitality employment. International Journal of Hospitality Management, 27(1), 76-86. 
Testa, M. R., Skaruppa, C., \& Pietrzak D. (1998). Linking job satisfaction and customer satisfaction in the cruise industry: Implications for hospitality and travel organizations. Journal of Hospitality \& Tourism Research, 22(1), 4-14.

Wan, Y., \& Kong, W. (2012). Career perceptions of heritage management students: A case study of undergraduates in Macao. Journal of Hospitality \& Tourism Education, 24(1), 5-15.

Wan, Y., Wong, I., \& Kong, W. (2014). Student career prospect and industry commitment: The roles of industry attitude, perceived social status, and salary expectations. Tourism Management, 40, 1-14.

Wong, C. K., \& Liu, J. (2009). Work values and their relationships with career choice: A segment-based approach to understanding hospitality and tourism management students in China. Journal of China Tourism Research, 5, 339-363.

Xu, F. J. (2005). How should tourism educational organizations develop themselves? Retrieved from http://www.itsqq.com/a/mu/jx/a/c/2005-04-25/21370

Zhao, W. (2008). Factors of the "Potential Brain Drain" of hotel management students and the countermeasures. Journal of Tourism College of Zhejiang, 4(4), 78-81.

Zeithaml, V., Bitner, M., \& Gremler, D. (2006). Service marketing: Integrating customer focus across the firm (4th ed.). New York, NY: McGraw-Hill.

Zheng, Y. (2008). Research on the motivations of tourism management students' career choice. Journal of Dalian Official, 23(10), 38-39. 